\title{
Т.А. КОСТЕЦЬКА
}

Тетяна Анатоліївна Костецька, кандидат юридичних наук, дочент, старший науковий співробітник Інституту держави і права імені В.М. Корецького НАН України*

ORCID: 0000-0002-3841-4925

\section{УНІТАРИЗМ I НОВА ПАРАДИГМА ДЕРЖАВНОЇ ІНФОРМАЦІЙНОЇ ПОЛІТИКИ УКРАЇНИ}

Постановка проблеми у заявленому контексті є виправданою і актуальною не тільки з потреб доктринального походження. Об'єктивно коло питань, що становлять сформульовану проблематику, зумовлених рядом змін у реаліях політико-правового життя держави і українського суспільства, потребують першочергового вирішення, є досить широким і багатогранним.

Серед таких конкретно окреслених напрямів для вітчизняної юридичної науки є, зокрема, вироблення нової парадигми раціональної, ефективної територіальної, просторової організації публічної влади в умовах українського унітаризму з використанням світового і вітчизняного досвіду.

Водночас науково підтверджено, що практика світового конституціоналізму досі ще не виробила єдиного стандарту організації публічної влади у демократичній, правовій державі.

Унітаризм, як конституційно-правовий феномен, як один із основоположних принципів конституційного ладу (ч. 2 ст. 2 Основного Закону України), за обгрунтованою думкою, є теоретичним відображенням політичної, соціально-економічної, екогуманістичної, інформаційної та націобезпекової стратегії та практики розвитку Українського народу і української державності, об'єктивно виступає своєрідним плацдармом для впровадження унітаристської ідеології в конституційно-правове життя і суспільні відносини1.

Реалії інтенсивної трансформації цивілізаційних процесів розвитку, існуючих тенденцій у багатьох державах світу, у тому числі й в Україні, де, зокрема, має місце багаторічний політичний, науковий дискурс щодо найбільш дієвої для держави форми державної організації влади - унітарної чи федеральної, ставлять перед дослідниками складні наукові завдання і потребують нових підходів до їх вирішення.

Аналіз напрямів досліджень та публікацій останнього періоду свідчить, що розробці різних аспектів проблем унітарної форми державно-територіального устрою присвячено чимало наукових праць як зарубіжних, так і вітчизняних дослідників. Теоретичним підгрунтям для висвітлення заявленої проблематики $\epsilon$ наукові праці О. Батанова, А. Гетьмана, А. Глазиріна, А. Колодія, В. Кравченка, І. Кресіної, В. Міщука, Н. Мяловицької, В. Погорілка, О. Стойко, С. Телешуна, В. Федоренка, В. Шаповала та ін.

В умовах, коли розвиток інформаційно-комунікаційних технологій, інформаційних ресурсів, інформаційної інфраструктури тощо значною мірою впливають на життєздатність сучасних націй, реалізацію державних інтересів, ступінь захисту від інформаційних впливів, інформаційна складова набуває дедалі більшої ваги, виключної актуальності для будь-якої сучасної держави.

У контексті потреби вироблення принципово нової стратегії входження українського суспільства в трансграничний простір, інтеграції у міжнародні телекомунікаційні мережі, освоєння міжнародних стандартів інформаційного обміну та захисту інформації, в умовах жорсткої міжнародної конкуренції, а також складної ситуації, зумовленої збройною та інформаційною агресією, як ніколи, актуалізується теоретико-прикладна проблема розроблення нової парадигми державної інформаційної політики, ії правового регулювання.

Слідуючи визначеній тематиці роботи, є усвідомлення того, що продуктивним може стати комплексний аналіз впливу форми державно-територіального устрою на реалізацію їі інформаційної політики, дієвість здійснення тих чи інших функцій державою.

Такий науковий підхід, на наш погляд, може стати не тільки важливою науковою проблемою в об'єктивному процесі формування національної доктрини унітаризму, а й концептуально ії збагатить.

Так само можна вести мову в контексті розроблення концептуально нового підходу до формування концепту державної інформаційної політики. Йдеться про взаємний вплив в даному випадку унітарного розвитку держави і їі інформаційної політики, наслідок чого виособлюються іiі цілі, методи, способи ії здійснення тощо.

Розробкою окремих аспектів державної інформаційної політики, зокрема, забезпечення інформаційної безпеки займаються такі, наприклад, вчені-юристи, як: І. Арістова, К. Беляков, В. Брижко, О. Довгань, Б. Кормич, А. Марущак, О. Олійник, І. Сопілко та ін. Не відкидаючи значущості доробку вітчизняних правознавців у названому напрямі, припускаємо, що на сьогодні системні засади формування концепції відповідної політики, її правового регулювання всебічно не визначені.

Чималий масив досліджень стосується формування та реалізації державної інформаційної політики, що здійснювалась у минулі роки при відносно стабільній для України зовнішньо- та внутрішньополітичній

() Т.А. Костецька, 2020

${ }^{*}$ Tetiana Kostetska, Ph.D. in Law, Senior Researcher of V.M. Koretsky Institute of State and Law of the NAS of Ukraine 
ситуації, тоді як нинішні реалії фактичної інформаційної війни проти українського суспільства вимагають пошуку нових засобів державного регулювання інформаційної сфери.

Що стосується порушених у даній роботі проблем, пов'язаних, зокрема, з особливостями здійснення державної інформаційної політики в унітарній державі, слід констатувати, що вони не отримали грунтовного аналізу у юридичній літературі. Існують окремі напрацювання у вітчизняній політичній науці щодо функціонування інформаційно-комунікативних систем у суспільствах з різними політичними системами ${ }^{2}$.

Мета статті - висвітлення проблематики вдосконалення теоретико-правових засад інформаційної політики держави в сучасних умовах, формулювання деяких концептуальних засад іiї сутності, змісту, іiі значення для поглиблення доктринальних засад сучасного унітаризму як конституційно-правового інституту.

Основні результати дослідження. Новітні виклики і загрози зумовлюють і потребують посилення ролі будь-якої держави у функціонуванні національного інформаційного простору, вироблення і реалізації комплексної концепції його розвитку.

Доведено, що суверенітет держави нерозривно пов'язаний із ії інформаційним суверенітетом, значення захисту якого у зв’язку з інтенсифікацією інформаційних впливів глобального інформаційного простору на національні інформаційні ресурси зростає. Свого часу Законом України від 4 лютого 1998 р. «Про національну програму інформатизації» (Відомості Верховної Ради України. 1998. № 27-28. Ст. 181) інформаційний суверенітет держави було визначено як здатність держави контролювати й регулювати потоки інформації зпоза ії меж з метою додержання законів України, прав і свобод громадян, гарантування національної безпеки (ст. 1).

Зауважимо, що у сучасний період поняття державного суверенітету в інформаційній сфері перебуває в процесі трансформації: на заміну концепції суверенітету як функції контролю і регулювання інформаційних потоків регуляторної монополії всередині держави та колективної монополії держав на участь у міжнародному процесі зовні приходить доктрина державного суверенітету як «відповідальності за захист» інформаційної безпеки ${ }^{3}$.

У сучасній вітчизняній науковій літературі інформаційний суверенітет трактується, наприклад, як інформаційна незалежність держави в частині здатності регулювання інформаційних потоків 3 метою забезпечення суверенітету України на всій їі території, а також гарантування неупередженості (об'єктивності) інформації про неї в глобальному інформаційному просторі ${ }^{4}$.

Очевидно, що для України інформаційний напрям державної діяльності вже тривалий період стає стійким і постійним, реальним, значимість якого в перспективі буде тільки посилюватися5.

Доведено, що сутність держави виявляється не стільки в меті та завданнях, що ставляться чи декларуються, а в діяльнісному аспекті. Йдеться про формування та реалізацію ефективної інформаційної політики держави, яка є ідеологічно-правовою основою ії інформаційної функції. Юридичне регламентування комплексного інституту інформаційної політики забезпечило підгрунтя об'єктивізації такої потенційної функції, якою стала інформаційна функція, в реально здійснювану діяльність Української держави.

Держава конституційно зобов’язана забезпечувати в межах наявних у неї форм, засобів встановлених насамперед на конституційному рівні цілого кола інформаційних прав людини і громадянина, гарантувати рівень інформаційної безпеки (визначальними є положення ст. ст. 17, 31, 32, 34 Основного Закону України). Саме інформаційна політика, за висловом науковців, стає основним засобом вираження позиції держави $\mathrm{i}$ управління соціальними процесами під час переходу нашої країни в іншу формацію - до інформаційного суспільства.

Слід сказати, що ступінь розбудови подібного суспільства для України у вже визначених на законодавчому рівні параметрах (ст. 1 Закону України «Про основні засади розвитку інформаційного суспільства в Україні на 2007-2015 роки» від 9 січня 2007 р., який на черговому етапі проведення інформаційної політики став спробою комплексного підходу до вирішення проблем) є показником у сучасному співтоваристві реальної оцінки будь-якої держави, її розвитку у всіх напрямах. Без розширеної аргументації, оскільки це предмет для окремого аналізу, можна припустити, що ефективніше, на наш погляд, такі процеси здійснюються в умовах унітарної держави.

У реаліях, коли новітні інформаційні технології вивели суспільні комунікації на принципово інший рівень, коли для України першочерговими завданнями $\epsilon$, в тому числі, захист національних інтересів в інформаційній сфері, чимало існуючих проблем залишаються неврегульованими, невирішеними, в тому числі і на правових засадах. Типова ситуація не змінюється вже довготривалий період ${ }^{6}$

Недоліки формування та реалізації державної інформаційної політики, іноді ії фактична відсутність у багатьох напрямах функціонування інформаційних відносин, в тому числі протидії інформаційним війнам, відсутність системного і комплексного підходу до нормативно-правового забезпечення відповідних процесів, а також до прогнозування зовнішніх та внутрішніх загроз іiі національній безпеці, вироблення стратегії входження українського суспільства в трансграничний інформаційний простір тощо неодноразово були предметом висвітлення вітчизняних юристів, представників суміжних наук.

Сьогодні актуалізується проблема, як наголошується вченими-юристами, усвідомлення тенденції щодо необхідності розроблення концептуально нового підходу до вироблення засад формування концепції державної інформаційної політики, іiі правового регулювання.

На часі - повернення до розгляду у Верховній Раді та прийняття Концепції державної інформаційної політики в Україні, яка б визначала основні напрями, засади, принципи державної діяльності, механізми ііі реалізації, систему цілеспрямованих заходів розв'язання існуючих проблем тощо. Це б дало змогу, зокрема, сформувати на системному рівні пропозиції до внесення змін до чинного законодавства 3 метою його вдосконалення. 
У контексті загального завдання, мети розроблення нової парадигми інформаційної політики держави окремо слід звернути увагу на формування ії понятійно-категоріального апарату: шляхом використання вже введених у науковий, нормативно-правовий обіг, можливого їх переосмислення; обгрунтування введення нових категорій. Зокрема, важливе значення мають теоретичні питання аналізу змісту досліджуваного поняття.

Чинне законодавство не містить нормативного визначення державної інформаційної політики, на відміну від первісної редакції Закону України «Про інформацію» від 2 жовтня 1992 р., який визначав цю категорію як сукупність основних напрямів і способів діяльності держави з отримання, використання, поширення і зберігання інформації (ст. 6). Згодом законодавець відмовився від визначення поняття названої категорії, обмежившись закріпленням (в основному перенесенням з деякою модифікацією із старої редакції законодавчого акта) лише основних напрямів державної інформаційної політики (ст. 3 Закону України «Про інформацію» в редакції від 13 січня 2011 р.).

Аналіз джерельної бази свідчить про відсутність єдиного методологічного підходу при визначенні дефініції державної інформаційної політики. Зокрема, у сучасній вітчизняній літературі окремі науковці визначають названу категорію як діяльність органів державної влади та місцевого самоврядування, суспільних інституцій і громадських об'єднань та створення ними засобів масової комунікації, спрямованої на вироблення й реалізацію правових, політичних та економічних умов функціонування інформаційної системи, що випливають із сукупності цінностей українського суспільства7. Інші зводять іiі до поняття інформаційної (інформаційно-комунікативної) функції

Постановка питання про взаємовплив, зокрема, форми державно-територіального устрою і державної інформаційної політики, зумовлює сутнісний аналіз ще таких категорій - «інформаційна сфера» та «інформаційний простір», широковживаних у спеціальній науковій літературі, сприйнятих як легальних, без нормативно-правового їх тлумачення на рівні дефініції.

При цьому нагадаємо, що складовими, в даному випадку, сучасного унітаризму є такі поняття, як «державний устрій», «державно-територіальний устрій», «територіальна організація влади», в розуміння яких концептуально закладений т.зв. просторовий вимір організації держави.

У сучасних дослідженнях інформаційна сфера здебільшого визначається, зокрема, як «...предметнотериторіальний, системно-структурний та юрисдикційний простір...»" ${ }^{9}$, здійснення певної інформаційної діяльності.

Не заперечуючи методологію подібного підходу і підкреслюючи існуючу наукову тенденцію щодо визначення змістовного наповнення названого явища через згаданий вище в іншому контексті «просторовий вимір», допустимо, що він може стати продуктивним щодо аналізу інформаційно-функціональної складової парадигми сучасного унітаризму.

Вищенаведене у підсумку дає змогу зробити висновок, що заявлена проблематика є досить складною, багатогранною i, безумовно, заслуговує на подальше розроблення, наукове осмислення комплексу проблем, пов'язаних із розробкою та втіленням у життя державної інформаційної політики, їі правовими засадами. Поглибленого теоретичного аналізу потребують також питання взаємовпливу форми державно-територіального устрою на здійснення державою інформаційної діяльності в умовах такого феномена, яким $\epsilon$ інформаційне суспільство.

1 Батанов О.В. Конституційно-правова регламентація територіальної організації публічної влади в Україні в контексті доктрини унітаризму. URL: http://maup.com.ua/assets/files/expert/7/2.pdf (дата звернення: 15.06.2020).

2 Бондар Ю.В. Становлення та еволюція інформаційного простору України в процесі формування демократичної політичної культури українського суспільства: автореф. дис. ... канд. політ. наук: 23.00.03. Київ: Нац. пед. ун-т ім. М.П. Драгоманова. 2010. С. 8-9, 13.

3 Пазюк А.В. Міжнародно-правове регулювання інформаційної сфери (теоретичні і практичні аспекти): автореф. дис. ... д-ра юрид. наук. Київ, 2016. С. 29.

4 Довгань О.Д. Теоретико-правові основи забезпечення інформаційної безпеки України : автореф. дис. ... д-ра юрид. наук. Київ, 2016. С. 28-29.

5 Костецька Т.А. Інформаційна функція держави: конституційні та інституаційні аспекти. Державо $і$ право: зб. наук. праць. Юрид. і політ. науки. Київ, 2010. Вип. 47. С. 113-119.

6 Сопілко I.M. Правове регулювання державної інформаційної політики у сфері європейської та євроатлантичної інтеграції. Порівняльно-аналітичне право. Київ, 2014. № 2. С. 256-258. Костецька Т.А. Актуальні питання взаємовідносин органів публічної влади та інститутів громадянського суспільства (комунікативні аспекти). Правова держава. Щорічний збірник наукових пращь. Київ, 2017. Вип. № 28. С. 190, 194-195.

${ }^{7}$ Нестеряк Ю.В. Державна інформаційна політика України: теоретико-методологічні засади : монографія. Київ: НАДУ. 2014. C. 50 .

8 Інформаційна складова державної політики та управління: монографія / за заг. ред.: Грицяк Н.В. К. К.І.С. 2015. С. 34.

9 Заярний О.А. Адміністративна деліктологія в інформаційній сфері: проблеми теорії і практики : автореф. дис. ... д-ра. юрид. наук : 12.00.07. Київ, 2018. С. 8.

\section{Резюме}

Костецька T.A. Унітаризм і нова парадигма державної інформаційної політики України.

Обгрунтовується доцільність розроблення нового концепту політики держави в інформаційному просторі, ії правового регулювання. Звертається увага на взаємозвязок державної інформаційної політики і державної інформаційної функції. На підставі аналізу положень чинного законодавства, спеціальної літератури вказується на існуючі проблеми понятійно-категоріального апарату досліджуваної тематики, необхідність його вдосконалення. 
Ключові слова: державний устрій, унітаризм, національний інформаційний простір, інформаційна сфера, інформаційна політика держави.

\title{
Резюме
}

Костецкая Т.А. Унитаризм и новая парадигма государственной информацинной политики Украины.

Обосновывается целесообразность разработки нового концепта государственной политики в национальном информационном пространстве, ее правового регулирования. Обращается внимание на взаимную связь государственной информационной политики и информационной функции государства. Отдельно указывается на проблемы понятийно-категориального аппарата исследуемой тематики, необходимость его усовершенствования.

Ключевые слова: государственное устройство, унитаризм, национальное информационное пространство, информационная сфера, информационная политика государства.

\section{Summary}

Tetiana Kostetska. Unitarism and a new paradigm of the Ukraine state information policy.

The article purpose is to highlight the issue of improving the theoretical and legal foundations of state information policy in modern conditions, to formulate some conceptual foundations of its essence, content as a complex legal institution. And also to deepen the doctrinal grounds of modern unitarism as a constitutional and legal institution. sidered.

Some aspects of the influence of the state-territorial organization form on the implementation of state information policy are con-

The need to develop a fundamentally new strategy for the entry of Ukrainian society into the cross-border space, integration into international telecommunications networks, development of international standards of information exchange and information protection is emphasized.

The expediency of developing a new paradigm of state information policy, its legal regulation is substantiated.

Attention is paid to the relations between state information policy and state information function.

Deficiencies in the formation and implementation of the national state information policy are analyzed separately. These are: the actual lack of information relations in many areas, including countering information wars against Ukraine.

It is said about the lack of a systematic and comprehensive approach to regulatory and legal support of information policy measures and other shortcomings of the modern state policy strategy.

Based on the analysis of the current legislation provisions, special literature, attention is paid to the problems of the conceptual and categorical apparatus of the researched subject, the need for its improvement.

In particular, it is an analysis of the content of such key categories as "state information policy", "information sphere", "national information space". Methodological approaches to the essential characteristics of these concepts differ both in domestic special literature and in foreign. This issue has extremely practical significance

Key words: state system, unitarism, national information space, information sphere, state information policy.

DOI: 10.36695/2219-5521.2.2020.35

УДК 342.98: 347.962.1

\section{л.В. ТРОФІМОВА}

Лариса Вімаліївна Трофімова, кандидат юридичних наук, доцент, старший науковий співробітник НТУ «Дніпровська політехніка»*

ORCID: 0000-0002-6768-9290

\section{ПРОБЛЕМНІ ПИТАННЯ ЯКОСТІ КВАЛІФІКАЦІЙНОГО ОЦІНЮВАННЯ СУДДІВ}

\author{
Оцінка - це найгостріший інструмент, використання \\ якого потребує величезного вміння і культури.
}

В. Сухомлинський

Постановка проблеми. Угодою про асоціацію між Україною, з однієї сторони, та Європейським Союзом, Європейським співтовариством з атомної енергії і їх державами-членами, з іншої сторони (ратифікованої Законом України від 16 вересня 2014 р. № 1678-VII) передбачено здійснення заходів, спрямованих на активізацію обміну інформацією, практикою та досвідом, для заохочення більш тісного співробітництва в галузі професійно-технічної освіти та навчання, зокрема 3 метою: створення національних механізмів для покращення прозорості та визнання кваліфікацій та компетенцій, використовуючи, коли це можливо, досвід ЄС (ст. 432). Згідно зі ст. 347 цієї Угоди та п. 1461 Плану заходів з виконання Угоди (постанова КМУ від 25 жовтня 2017 р. № 1106) передбачено здійснення заходів імплементації стандартів та методик INTOSAI. У Звіті про результати аудиту ефективності використання бюджетних коштів на забезпечення діяльності Вищої кваліфікаційної комісії суддів України (далі - ВККСУ), затвердженого рішенням Рахункової палати від 25 червня 2019 р. № 14-3 зазначено, що «результативні показники паспортів бюджетної програми за

(C) Л.В. Трофрімова, 2020

* Larysa Trofimova, Ph.D. in Law, Associate Professor, Senior Researcher of Dnipro Polytechnic National Technical University 